\title{
Anophthalmia in a Common Asian Toad, Duttaphrynus melanostictus (Amphibia: Anura: Bufonidae), from the Eastern Ghats of India
}

\author{
Khan Ashaharraza ${ }^{1}$ and Cuckoo Mahapatra ${ }^{2}$
}

\begin{abstract}
${ }^{1}$ Department of Wildlife and Biodiversity Conservation, North Orissa University, Baripada-757003, Odisha, India (ashaharrazakhan@gmail.com)
\end{abstract} ${ }^{2}$ Department of Zoology, North Orissa University, Baripada-757003, Odisha, India (cuckoomahapatra@gmail.com)

$\mathrm{D}$ eformities in wild amphibians have been an alarming threat for some time (e.g., Hall and Henry 1992). In India, Daniels (2003) and Gurushankara et al. (2007) have recorded anuran deformities attributed to the effects of pesticides, chemical fertilizers, and large-scale intensive agriculture in the Western Ghats. Anophthalmia and microphthalmia are deformities involving the absence of an eye and the presence of a small eye within the orbit, respectively (Verma and FitzPatrick 2007).

The Common Asian Toad (Duttaphrynus melanostictus) is widely distributed throughout southern and southeastern Asia (Frost 2020). The species is invasive on the Andaman and Nicobar Islands, Lakshdweep, Madagaskar, and Oceania (Church 1960; Csurhes 2010; Kolby 2014).
During a recent amphibian survey in the Similipal Biosphere Reserve, Odisha, we found an anophthalmic adult Duttaphrynus melanostictus (Fig. 1) in the forest around Lulung, Mayurbhanj District $\left(21.9349^{\circ} \mathrm{N}, 86.5332^{\circ} \mathrm{E}\right)$. The left eye was completely absent, although the upper eyelid covered the orbit. Another individual collected in the larval stage by the second author in Baripada, Odisha $\left(21.9268^{\circ} \mathrm{N}\right.$, $86.7685^{\circ} \mathrm{E}$ ) had a similar deformity. Chemical contamination of water with pollutants, pesticides, herbicides, steroid-mimicking contaminants, retinoids and retinoid mimics, petrochemicals, and metals are known to kill or cause such deformities in amphibians (Hall and Henry 1992; Chambon 1993; Kirk 1998; Marco et al. 1999; Hayes et al. 2002; Degitz et al. 2003), although ultraviolet radiation, parasitic infections, and

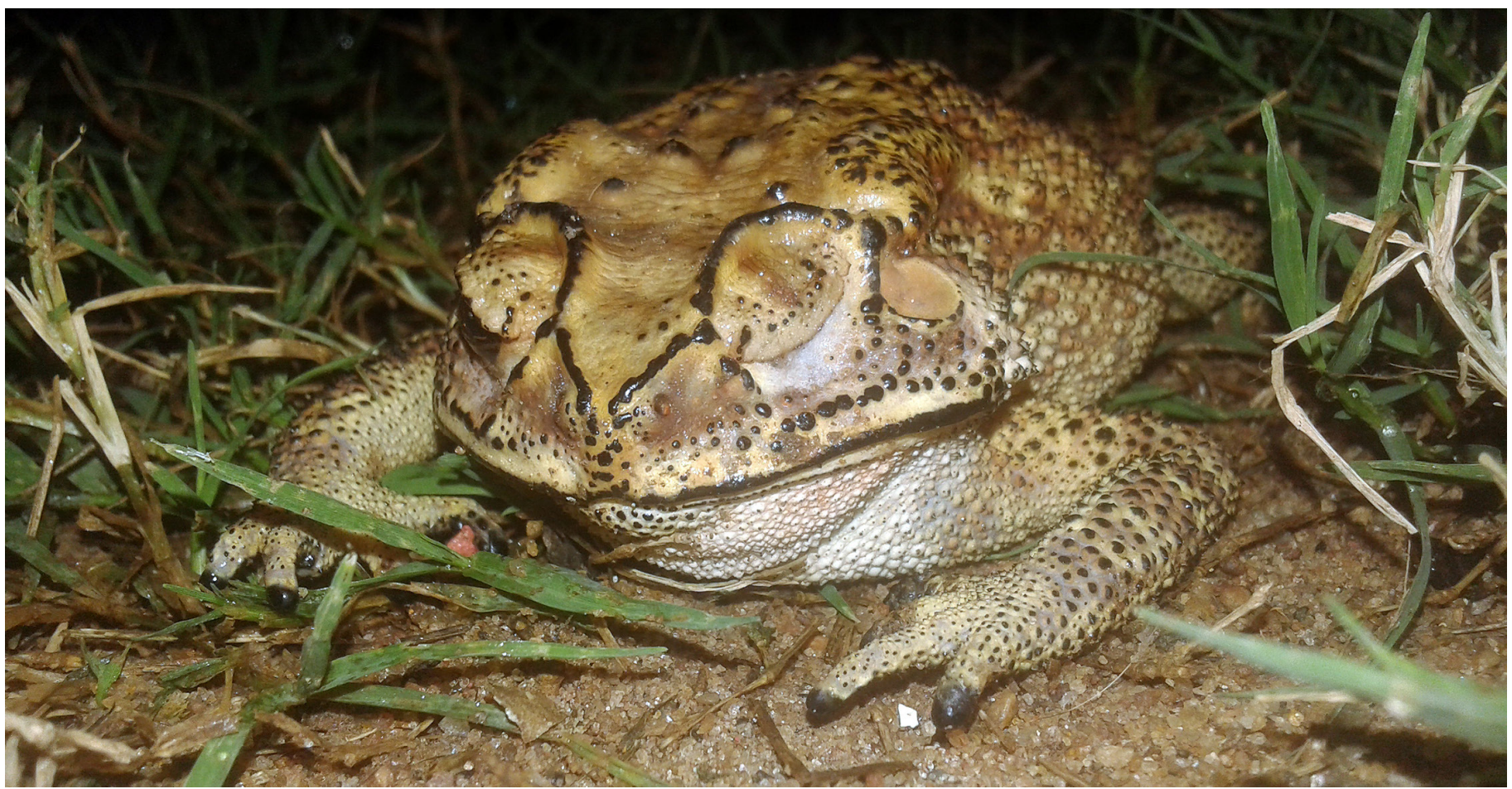

Fig. 1. Anophthalmia in Duttaphrynus melanostictus from the Similipal Biosphere Reserve in the Eastern Ghats of India. Photograph by Khan Ashaharraza.

Copyright () 2020. Khan Ashaharraza. All rights reserved. 
global warming have also been implicated (Ankley et al. 2002; Johnson et al. 2001; Schoff et al. 2003).

Lulung is a hamlet situated adjacent to a natural spring. Although in the protected transitional buffer zone around the Similipal Biosphere Reserve, most parcels of land are utilized for agriculture, livestock production, and tourism. Rice is the predominant crop in the region. However, neglecting indigenous varieties of rice, cultivators are increasingly planting hybrid varieties for better production and commercial values. These varieties require the extensive use of pesticides in the otherwise pristine habitats of the Eastern Ghats. Surface runoff from agricultural fields sprayed with pesticides might be responsible for morbidity in larval and adult anurans. In fact, many pesticides that are widely used in India have already been shown to cause deformities in larval $D$. melanostictus (Mercy and Andrews 2000).

An optical deformity in D. melanostictus has been reported only once in India (Hippargi et al. 2010) and deformities reported herein are the first from the Eastern Ghats. Further surveys and experiments are required to evaluate the hazardous effects of chemical pollutants on amphibian populations in the region.

\section{Literature Cited}

Ankley, G.T., S.A. Diamond, and J.E. Teitge. 2002. Assessment of the risk of solar ultraviolet radiation to amphibians. I. Dose-dependent induction of hindlimb malformations in the Northern Leopard Frog (Rana pipiens). Environmental Science \& Technology 36: 2853-2858.

Chambon, P. 1993. The molecular and genetic dissection of the retinoid signalling pathway. Gene 135: 223-228.

Church, G. 1960. The invasion of Bali by Bufo melanostictus. Herpetologica 16: 15-21.

Csurhes, S. 2010 (updated 2016). Invasive Animal Risk Assessment: Asian spined toad Bufo melanostictus. Department of Agriculture and Fisheries, Biosecurity Queensland, State of Queensland, Yeerongpilly, Queensland, Australia.
Daniels, R.J. 2003. Impact of tea cultivation on anurans in the Western Ghats. Current Science 85: 1415-1422.

Degitz, S.J., G.W. Holcombe, P.A. Kosian, J.E. Tietge, E.J. Durham, and G.T. Ankley. 2003. Comparing the effects of stage and duration of retinoic acid exposure on amphibian limb development: Chronic exposure results in mortality, not limb malformations. Toxicological Sciences 74: 139-146.

Frost, D.R. 2020. Amphibian Species of the World: An Online Reference. Version 6.1. American Museum of Natural History, New York, New York. <https://amphibiansoftheworld.amnh.org>.

Gurusankara, H.P., S.V. Krishnamurthy, and V. Vasudev. 2007. Morphological abnormalities in natural populations of common frogs inhabiting agro-ecosystems of central Western Ghats. Applied Herpetology 4: 39-45.

Hall, R.J. and P.F.P. Henry 1992. Assessing effects of pesticides on amphibians and reptiles. Herpetological Journal 2: 65-71.

Hayes, T.B., A. Collin, M. Lee, M. Mendoza, N. Noriega, A.A. Stuart, and A. Vonk. 2002. Hermaphroditic, demasculanized frogs after exposure to the herbicide atrazine at low ecologically relevant doses. Proceedings of the National Academy of Sciences 99: 5476-5480.

Hippargi, R.V., L.J. Harkare, and A.D. Garg. 2010. Observations on developmental abnormalities in a wild specimen of Duttaphrynus melanostictus (Schneider, 1799) from Nagpur, Maharashtra, India. Frogleg 14: 16-20.

Johnson, P.T.J., K.B. Lunde, E.G. Ritchie, J.K. Reaser, and A.E. Launer. 2001. Morphological abnormality patterns in a California amphibian community. Herpetologica 57: 336-352.

Kirk, J.J. 1988. Western-spotted Frog (Rana pretiosa) mortality following forest spraying of DDT. Herpetological Review 19: 51-53.

Kolby, J. 2014. Stop Madagascar's toad invasion now. Nature 509: 563.

Marco, A., C. Quilchano, and A.R. Blaustein. 1999. Sensitivity to nitrate and nitrite in pond-breeding amphibians from the Pacific Northwest, USA. Environmental Toxicology and Chemistry 18: 2836-2839.

Mercy, C.U. and M.I. Andrews. 2000. Effect of endosalfan on the hatching rate and larval survival of Common Indian Toad (Bufo melanostictus Schneider), pp. 615-617. In: Proceedings of the 12th Kerela Science Congress, Government of Kerala, Thiruvananthapuram, Kerala, India.

Schoff, P.K., C.M. Johnson, A.M. Schotthoefer, J.E. Murphy, C. Lieske, R.A. Cole, L.B. Johnson, and V.R. Beasley. 2003. Prevalence of skeletal and eye malformations in frogs from north-central United States: Estimations based on collections from randomly selected sites. Journal of Wildlife Diseases 39: 510-521.

Verma, A.S. and D.R. FitzPatrick. 2007. Anophthalmia and microphthalmia. Orphanet Journal of Rare Diseases 2: 47. 